\title{
The rabbit as an animal model for experimental surgery
}

\author{
O coelho como modelo animal para cirurgia experimental
}

\author{
Mônica Diuana Calasans-Maia', Maria Lucia Monteiro" ${ }^{\mathrm{II}}$, Fábio Oliveira Áscoli'II, José Mauro Granjeiro ${ }^{\mathrm{IV}}$

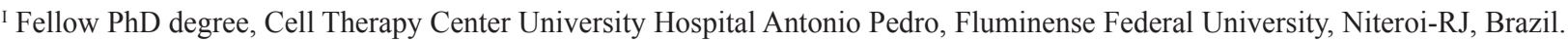 \\ ${ }^{\text {II }}$ Full Professor, School of Veterinary Medicine, Fluminense Federal University, Niteroi-RJ, Brazil. \\ ${ }^{\text {III }}$ Fellow PhD degree, Pharmacodynamics Department, Oswaldo Cruz Foundation, Rio de Janeiro, Brazil. \\ Iv Associate Professor, Biology Institute, Fluminense Federal University, Niteroi-RJ, Brazil.
}

\begin{abstract}
The white New Zealand rabbit (Oryctolagus cuniculus) is frequently used as a model for in vivo studies. However, information on precautions when using this animal as an experimental model is limited. This review of the literature covers the gamut from the selection of the animal model all the way to its death, and describes procedures for transporting, raising, breeding, housing, administering anesthesia and handling so as to rationalize the utilization of this species while exploiting its unique characteristics. Based upon the literature and our own experience with white New Zealand rabbits, we conclude that the rabbit is an adequate model for experimental surgery.

Key words: Biocompatible Materials. Animal Experimentation. Rabbits.

\section{RESUMO}

O coelho branco da Nova Zelândia (Oryctolagus cuniculus) é freqüentemente utilizado como modelo em estudos in vivo. Contudo, as informações referentes aos cuidados no emprego deste animal como modelo experimental são limitadas. Esta revisão da literatura pretende rever a literatura desde a seleção do modelo animal até a sua morte, enfatizando, os procedimentos para transporte, criação, reprodução, comportamento, acomodação, anestesia e manejo dos animais, de forma a racionalizar a utilização desses animais reconhecendo as características próprias dessa espécie. Conclui-se que o coelho constitui um modelo adequado e viável para cirurgia experimental.

Descritores: Materiais Biocompatíveis. Experimentação Animal. Coelhos.
\end{abstract}

\section{Introduction}

The use of animals in biomedical research has been recommended for perfecting and validating existing procedures ${ }^{1,2,3}$, developing new materials $s^{4,5,6}$ and understanding the various physiological and pathological processes ${ }^{7,8,9}$ because there are no in vitro models capable of fully mimicking the complexity of the human organism.

An animal model is an imitation, an object that represents something or someone, that is similar to or an image of another. It must have enough characteristics in common with the object for the experiment and be able to be fully manipulated without the limitations of that object ${ }^{10}$. Models are evaluated according to their suitability, namely, whether they can represent all the aspects of a given empirical process with enough precision to meet the project's specifications ${ }^{10}$.

White New Zealand rabbits (Oryctolagus cuniculus) are frequently used in a variety of experiments, including orthopedics $^{2,5,7,8}$ and craniomaxillofacial surgery ${ }^{4,9}$. However, information on their handling and surgical procedures is sparse and difficult to find. This article reviews the available literature on the advantages and disadvantages of using rabbits for research, their maintenance and housing, transport, reproduction, anesthetics, pre- and post-operative procedures, and euthanasia.

\section{Review of the literature}

The various situations in which animal research was needed and used have provoked much ethical, bioethical, philosophical and religious reflection about research particularly on vertebrates $^{12,13}$. Aristotle (384-322 B.C.), Galen (131-201 A.D.), Francis Bacon (1561-1626), William Harvey (1578-1657) and Claude Bernard (1813-1878) represent a few of the authors who have tackled this field ${ }^{14}$. However, the need to preserve human life only came to the forefront during World War $\mathrm{II}^{10}$. It was the Nuremberg Code (1947) that determined that research on humans must be based on the results of animal experimentation - a position reinforced by the Helsinki Declaration in $1975^{14}$.

As equipment, procedures and drugs were developed, scientific investigation was performed in vitro, preferably in a standardized manner (International Organization for Standardization - ISO 10993-6, 1992) ${ }^{15}$, and in animals of small (rats, mice and guinea pigs) $)^{1,3,6}$, medium (rabbits, mini pigs, cats and dogs) , $^{4,2,7,9}$ and large size (sheep and pigs) (5, $^{5,16}$.

The choice of the model for an experiment is determined by factors such as cost, technical viability of the procedure, scientific principles, available data base and appropriateness of the model vis-à-vis the project ${ }^{12}$. We hereby present a selective review of the literature, and list the essential procedures for successful 
animal research, confirmed by our personal experience with more than sixty surgical procedures on white New Zealand rabbits focused on bone repair and biocompatibility of experimental prosthetic materials.

Advantages and disadvantages of using rabbits as experimental models

\section{$\underline{\text { Advantages }}$}

(a) Are easy to handle and observe;

(b) Permit working with a large number of individuals;

(c) Have short vital cycles (gestation, lactation and puberty);

(d) Permit standardization of the environment;

(e) Permit genetic standardization;

(f) Allow transplantation or transmission of tumors and there is a large amount of basic information available.

\section{Disadvantages}

(a) Live in a totally artificial environment;

(b) They have a standardized diet;

(c) When being studied, illnesses are artificially induced in most experiments ${ }^{9,17}$.

Rabbits are the medium-sized model of choice because they are readily available and easy to handle and observe ${ }^{14}$.

\section{Selecting the animal model}

Before choosing an animal, one needs to review the literature to find information on the model on which to perform the experiment. If there is more than one alternative, one should select the least phylogenetically developed animals available in sufficient quantity at the lowest $\operatorname{cost}^{10}$. This is why rodents, especially rats and mice, are used in most of the research ${ }^{12,14}$. The selection of the model becomes easier if the researcher has anatomical and clinical knowledge of the animal. Cardiac and respiratory rates vary considerably from one species to the next. Rabbits have a heart rate of around 200 beats per minute and a respiratory rate of 50 per minute ${ }^{14}$. Biologic data such as lifespan, developmental phases and reproductive characteristics are essential parameters to be controlled.

When research is performed on the appropriate animals, the information obtained approximates what can be expected in humans ${ }^{17}$ because the greater the physiological, anatomical and organic similarity, the more applicable the conclusions $1^{4}$. As to our own research focus, some similarities have already been reported regarding bone composition, remodeling and density between animal models and human beings ${ }^{18}$. For example, bone density and resistance to fractures are very similar in rabbits and humans ${ }^{19}$. Another important aspect in selecting an animal is the emotional attitude of the researcher, which may become an obstacle to carrying out the experiment, mainly in cases involving domestic animals (e.g., dogs and cats). This can be a serious problem in long experiments where the researcher may become emotionally attached to the animal.

Maintenance and other procedures in the animal colony

Newly arrived rabbits should be quarantined for a minimum of two weeks and examined for the most common diseases, which must be treated if needed ${ }^{9}$. Rabbits are easily infested with scabies, which is highly contagious and capable of damaging the airways and predisposing to pneumonia ${ }^{14}$. A quarantine also serves as a period of adaptation to the surroundings and the daily routine in the animal quarters. Animals that die during this period must be removed immediately and subjected to a post-mortem examination ${ }^{9,17}$. Adult rabbits are usually kept in individual galvanized mesh cages $(0.90 \times 0.60$ $\mathrm{x} 0.45 \mathrm{~m}$ ) hung at a height of $0.8 \mathrm{~cm}$ from the ground so that excrement can fall out into collecting trays ${ }^{4}$.

Between 12 and 14 hours of light is enough for the colony's circadian biorhythms ${ }^{20}$. There are three important lighting factors for the environment: 1) the duration of the period of light (hours of light vs. hours of darkness), 2) intensity, expressed in Lux (lumens $/ \mathrm{m}^{2}$ ), and 3) wavelength or color, expressed in Angstroms. Visible light stimulates photoreceptors, which are responsible for the photoperiodocity that in turn regulates circadian rhythms, reproductive cycles, locomotive activity, food and water consumption, body temperature, toxicity and effectiveness of drugs, and serum levels of lipids and other substances ${ }^{21}$. The animals should be routinely observed for food consumption and fecal characteristics. Daily human contact reduces stress during handling.

Sometimes there is aggressive behavior, however, social order is usually re-established spontaneously. The animals' well-being is threatened when: (1) there is not enough space for them to keep the minimum distance between each other; (2) there is not enough resting and feeding space for all the animals or when it causes competition among them; (3) regrouping is done too often. Animals should not be kept alone unless they are sick, and a minimum of visual contact should be maintained ${ }^{9,20}$.

\section{Transportation}

Animals should be transported only when surgical procedures are not performed in the animal quarters. Animals should be carried in their own cages. If it is impossible to transport them in individual cages, the males should be separated from the females in order to prevent undesired mating. If the transport is not done in vehicles with covers and temperature control, appropriate weather conditions must be chosen.

\section{Reproduction}

Rabbits are well known for breeding easily and rapidly. This is due to their reproductive cycle in which, for every 14-16 days of fertility, they are infertile for only1-2 days ${ }^{18}$. Various factors can influence this cycle: nutrition, light, temperature, sexual stimuli, and individual variations ${ }^{9}$. Female rabbits can have their ovulation induced by proximity to males, mechanical stimulation, or when mounted by another female, which can result in pseudocyesis where there is ovulation without fertilization ${ }^{17}$. Gestation lasts $30-32$ days and the size of the litter is between 5 and 8 young on the average.

A female is capable of 6 litters a year, totaling from 40 to 50 offspring ${ }^{14}$. These data are important in planning the production of rabbits for an experiment. The young are normally weaned at around thirty days, when they are introduced to food pellets and water. The animals generally reach the ideal weight for surgical procedures $(2500 \mathrm{~g}$ to $3000 \mathrm{~g}$ ) when they are four to five months old ${ }^{18}$. 


\section{Handling}

Gloves should always be worn when handling rabbits, which should be grasped by the skin in the dorso-cervical region. They should never be picked up by the ears because of a high probability of causing cervical luxation and death ${ }^{23}$.

\section{Anesthesia}

Preoperative fasting is not necessary because vomiting during induction of anesthesia does not occur in this species. The animals should be provided with water until approximately 60 minutes prior to starting the anesthesia. Anesthetic agents are selected based on the health of the animal and the duration and invasiveness of the procedure. Intramuscular agents can be used to produce immobilization and, if adequate analgesia is present, surgical anesthesia ${ }^{24}$. Ketamine alone produces immobility in most animals due to a marked increase in skeletal muscle tone. When administered in combination with a tranquilizer (acepromazine, diazepam, or midazolam) or $\alpha 2$-agonists (xylazine or medetomidine), muscle relaxation is enhanced and the duration of anesthesia is prolonged ${ }^{25}$. These combinations can produce significant respiratory depression and should always be supplemented with oxygen.

Anesthetic depth is more easily controlled with intravenous drugs and inhalant anesthetics than by the intramuscular route. Inhalant anesthesia can be utilized following sedation or intramuscular or intravenous induction. Isoflurane is preferred over halothane for induction and maintenance in order to decrease the recovery time and the risk of arrhythmias ${ }^{24}$. Careful monitoring of the anesthetized rabbit is essential to assure appropriate anesthesia depth for the procedure, to maintain an airway and correct ventilation, to support adequate circulation, to preserve renal function, and to maintain normothermia. The depth of anesthesia should be continuously assessed by monitoring devices, on whose availability it depends ${ }^{26}$. The prevention and control of pain are key to the practice of anesthesia. The perioperative analgesic protocol has an impact on patient well-being that often extends far beyond the immediate anesthetic period ${ }^{27}$.

\section{Shaving and antisepsis}

The region to be operated on should always be shaved before any antiseptic procedures. This can be done with a safety blade razor or electric shaver. All shaved hairs should be cleaned away to avoid contamination or an undesired inflammation in the experiment. Antisepsis of the region to be operated should be done with a colorless solution to avoid that the animal become distressed over a strange color on itself such as produced by iodine solutions. Soap and topical solutions containing chlorhexidine are the most recommended.

\section{Surgery}

Hypothermia can occur during prolonged anesthesia. A thermal mattress should be used provided it is turned off as soon as body temperature returns to normal $\left(38^{\circ} / 39^{\circ} \mathrm{C}\right)$. When surgery is performed in a cooled environment, the cooling should be turned off afterwards so as to allow the animal to accommodate gradually to the outside temperature, thereby avoiding any abrupt changes in body temperature and post-operative complications.
Basic surgical principles, such as bio-safety and minimization of the length of surgical time, should be adhered to for the prevention of secondary infections which may affect the experiment's outcome. It is recommended that methodologies be formulated in advance and followed, preferably preceded by a pilot study to identify critical aspects of the surgery, including the use of appropriate instruments for each procedure.

\section{Post-operative care}

Pre, trans and post-operative practices should be developed under the supervision of a veterinary surgeon. During the post-operative period, the animal may return to its cage and not require any intensive care if it shows relatively normal eating patterns and other physiological characteristics ${ }^{20}$. Post-operative analgesic administration is essential for reducing pain and stress and for restoring appetite and bowel movement ${ }^{17}$. Animals should be carefully evaluated during the first 24 post-operative hours, checking for signs of pain because even if they do not vocalize them, remaining quiet and immobile in the back of their cages may be a sign of distress ${ }^{17}$. The analgesic effect of non-steroid anti-inflammatory drugs may be maintained for 12-24 hours after injection as indicated by serum levels. Analgesic narcotics reduce perception and recognition of pain by interfering with opioid receptors. They are used extensively as analgesics and, in some cases, as an anesthetic. They can also be used for reversing the anesthesia while maintaining the analgesic effects. The reported side effects of narcotics on rabbits are respiratory depression, hypothermia and bradycardia ${ }^{17}$.

\section{Euthanasia}

Euthanasia can be accomplished easily, painlessly and without prior stress ${ }^{10}$. The technique preferred by veterinarians involves sedation followed by injection of a barbiturate. Sodium pentobarbital is the drug of choice because it acts fast and effectively ${ }^{4}$.

\section{Our experience}

We have now successfully carried out sixty surgical procedures in white New Zealand rabbits following the guidelines described above including ISO Standard 10993-6, in which we studied bone repair and biocompatibility of experimental prosthetic materials. All have been completed without any significant untoward results for either the animals or the research staff and with positive results towards evaluating hypotheses and explaining mechanisms. We are now in the process of fattening 30 additional rabbits for another series of experiments.

\section{Discussion}

Animal research in addition to clinical research on humans has contributed greatly to the understanding of the various physiological and pathological processes affecting humans ${ }^{22}$. The use of animals in experimental research must be based on scientific, ethical and legal principles. If the researcher keeps these three aspects in balance in his activities, he will succeed without compromising his work or his reputation ${ }^{12}$. Our development of appropriate research protocols reviewed by our institutional research ethics committees involving more than sixty 
surgical procedures on white New Zealand rabbits has allowed us to carry out projects with good quality, control and safety for both the researchers and the animals.

\section{Conclusion}

The rabbit is an adequate and viable model for experimental studies in various branches of medical and dental sciences if the guidelines and procedures described above are followed.

\section{References}

1. Sanada JT, Canova GC, Cestari TM, Taga EM, Taga R, Buzalaf MAR Análise histológica, radiográfica e do perfil de imunoglobulinas após a implantação de enxerto de osso esponjoso bovino desmineralizado em bloco em músculo de ratos. J Appl Oral Sci. 2003;11(3):209-15.

2. Miranda ES, Cardoso FTS, Filho JFM, Barreto MDR, Teixeira RMM, Wanderley AL, Fernandes KE. Estudo experimental comparativo no uso de enxerto ósseo orgânico e inorgânico no reparo de fraturas cirúrgicas em rádio de coelhos. Acta Ortop Bras. 2005;13(5):245-8.

3. Ferreira GR, Cestari TM, Granjeiro JM, Taga R. Lack of repair of rat skull critical size defect treated with bovine morphometric protein bound to microgranular bioabsorbable hydroxyapatite. Braz Dent J. 2004; 15(3):175-80.

4. Calasans-Maia MD, Rossi AM, Dias EP, Santos SRA, Ascoli F, Granjeiro JM. Stimulatory effect on osseous repair of zinc-substituted hydroxyapatite. Histological study in rabbit tibia. Key Engineering Materials. 2008;361-363:1269-72.

5. Mendes SC, Reis RL, Bovell YP, Cunha AM, van Blitterswijk CA, Bruijn JD. Biocompatibility testing of novel starch-based materials with potential application in orthopaedic surgery: a preliminary study. Biomaterials. 2001;22(14):2057-64.

6. Calasans-Maia MD, Fernandes GVO, Rossi AM, Dias EP, Almeida GDS, Mitri FF, Granjeiro JM. Effect of hydroxyapatite and zinc-containing hydroxyapatite on osseous repair of critical size defect in rat calvaria. Key Engineering Materials. 2008;361-3, 1273-6.

7. Castaneda S, Largo R, Calvo E, Rodriguez-Salvanes F, Marcos ME, Diaz-Curiel M, Herrero-Beaumont G. Bone mineral measurements of subchondral and trabecular bone in healthy and osteoporotic rabbits. Skeletal Radiol. 2006;35(1):34-41.

8. Dai KR, Xu XL, Tang TT, Zhu ZA, Yu CF, Lou JR, Zhang XL. Repairing of goat tibial bone defects with BMP-2 gene-modified tissue-engineered bone. Calcif Tissue Int. 2005;77(1):55-61.

9. Cardoso ES, Cançado, RP, Heitz C, Gerhardt de Oliveira, M. Estudo exploratório descritivo do emprego de coelhos brancos da Nova Zelândia
(Orytolagus cuniculus) como modelo animal na avaliação dos padrões de crescimento craniofacial. Revista Odonto Ciênc. 2007;22(55):66-71.

10. Fagundes DJ, Taha MO. Modelo animal de doença: critérios de escolha e espécies de animais de uso corrente. Acta Cir Bras. 2004;19(1):59-65.

11. Ferreira LM, Ferreira LRK. Experimental model: historic and conceptual revision. Acta Cir Bras. 2003;18(spe):1-3.

12. Petroianu A. Aspectos éticos na pesquisa em animais. Acta Cir Bras. 1996;11(3):157-64.

13. Silva PC. O Uso de animais de experimentação biomédica. Rev Med Cir. 1997;1:71-9.

14. Schanaider A, Silva PC. Uso de animais em cirurgia experimental. Acta Cir Bras. 2004;19(4):441-7.

15. International Organization for Standardization (ISO 10993-6). Biological Evaluation of medical devices - Part 6. Tests for local effects after implantation; 1992.

16. Gosain AK, Song L, Riordan P, Amarante MT, Nagy PG, Wilson CR, Toth JM, Ricci JL. A 1-year study of osteoinduction in hydroxyapatite-derived biomaterials in an adult sheep model: part I. J Orthop Res. 2006;24(5): 867-76.

17. Harcourt-Brown F. Textbook of rabbit medicine. Reed Educational and Professional Publishing Ltd; 2002.

18. Pearce AI, Richards RG, Milz S, Schneider E, Pearce SG. Animal models for implant biomaterial research in bone: a review. Eur Cell Mater. 2007;2(13):1-10.

19. Wang X, Mabrey JD, Agrawal CM. An interspecies comparison of bone fracture properties. Biomed Mater Eng. 1998;8(1):1-9.

20. Olfert ED. Rabbits. In: Canadian Council on Animal Care. Guide to the care and use of experimental animals. Ottawa: Conseil Canadien de Protection des Animaux (CCPA); 1993.

21. Merusse JLB, Lapichik VBV. Instalações e equipamentos. In: Manual para técnicos em bioterismo. 2ed. São Paulo: EPM; 1996.

22. Ferreira LM, Hochman B, Barbosa MVJ. Modelos experimentais em pesquisa. Acta Cir Bras. 2005;20 (2):28-34.

23. Schossler JE. A escolha, contenção e manuseio de animais de experimentação. Acta Cir Bras. 1993;8(4):166-8.

24. Cantwell SL. Ferret, rabbit, and rodent anesthesia. Vet Clin North Am Exot Anim Pract. 2001;4(1):169-91.

25. Fujimoto J. Laboratory animal anesthesia. In: Greene SA. Veterinary anesthesia and pain management secrets. Philadelphia: Hanley \& Belfus; 2002. p.299-306.

26. Aeschbacher G. Rabbit anesthesia. Bern (Switzerland) University of Bern; 1995. The Compendium on continuing education for the practicing veterinarian. vol 17, p. 1003-10.

27. Hellyer PW, Robertson AS, Fails AD. Pain and its management. In: Tranquilli WJ, Thurmon JC, Trimm, KA. Veterinary anesthesia and analgesia. 4ed. Blackwell; 2007. p.31-60.

\section{Correspondence:}

Conflict of interest: none Financial source: none

Mônica Diuana Calasans Maia

Av. Rui Barbosa, 582/501

22250-020 Rio de Janeiro - RJ Brazil

Phone: (55 21)8153-5884

monicacalasans@terra.com.br

jmgranjeiro@gmail.com

Received: January 14, 2009

Review: March 12, 2009

Accepted: April 15, 2009

\section{How to cite this article}

Calasans-Maia MD, Monteiro ML, Áscoli FO, Granjeiro JM. The rabbit as an animal model for experimental surgery. Acta Cir Bras. [serial on the Internet] 2009 July-Aug;24(4). Available from URL: http://www.scielo.br/acb 